\title{
Radionuclide contents and radiological risk to the population due to raw minerals and soil samples from the mining sites of quality ceramic and pottery industries in Akwa Ibom, Nigeria
}

\author{
N.N. JIBIRI ${ }^{1}$, N.U. ESEN ${ }^{1}$
}

(Manuscript received 16 October 2010, Accepted 21 December 2010)

ABSTRACT Samples of domestically produced industrial raw minerals and soil samples from three mining sites of quality ceramic/smelting and pottery industries in Akwa Ibom, Nigeria, were collected and analyzed for their ${ }^{226} \mathrm{Ra},{ }^{232} \mathrm{Th}$ and ${ }^{40} \mathrm{~K}$ contents using gamma-ray spectroscopy. The range of activity concentrations of the radionuclides in the industrial raw minerals were $17.55 \pm 1.63$ to $80.99 \pm 2.61 \mathrm{~Bq}^{-\mathrm{kg}^{-1}}$ for ${ }^{226} \mathrm{Ra}, 7.64 \pm 0.77$ to $23.94 \pm 0.92 \mathrm{~Bq} \cdot \mathrm{kg}^{-1}$ for ${ }^{232}$ Th and $63.22 \pm 3.43$ to $503.90 \pm$ 5.69 Bq. $\mathrm{kg}^{-1}$ for ${ }^{40} \mathrm{~K}$, while in the soil samples they varied from 2.87 to $34.78 \mathrm{~Bq} \cdot \mathrm{kg}^{-1}$, 7.02 to $24.47 \mathrm{~Bq} \cdot \mathrm{kg}^{-1}$ and 7.05 to $162.81 \mathrm{~Bq}^{\mathrm{kg}}{ }^{-1}$ for ${ }^{226} \mathrm{Ra},{ }^{232} \mathrm{Th}$ and ${ }^{40} \mathrm{~K}$, respectively. These results, along with the estimated absorbed dose rates, annual effective dose rates, radium equivalent $\left(R a_{e q}\right)$, external hazard index $\left(H_{e x}\right)$, internal hazard index $\left(H_{i n}\right)$ and representative of the gamma index $\left(I_{\gamma r}\right)$ are presented. The results obtained were below the internationally accepted safe limits. Therefore, the analyzed samples could be used in the local industries in the area as component raw materials and/or as building materials. Also, the mining activities of these minerals in the area have not significantly affected the natural radiation dose levels in the area, hence the resulting dose to the population is therefore considered generally low.

Keyword: Natural radionuclides / industrial raw minerals / radiological risk / population / Nigeria

RÉSUMÉ Contenu en radionucléides et risque radiologique aux populations d'échantillons de sols et de minéraux bruts issus de sites miniers des industries de la poterie et de la céramique de qualité à Akwa Ibom, Nigeria.

Des échantillons de minéraux bruts industriels produits domestiquement ainsi que de sols issus de trois sites miniers des industries de céramique de qualité/ et de Poterie situés à Akwa Ibom, Nigeria ont été collectés et analysés pour leur contenu en ${ }^{226}$ Ra, ${ }^{232} \mathrm{Th}$ and ${ }^{40} \mathrm{~K}$ par spectrométrie gamma. Le niveau d'activité en radionucléides dans les minéraux bruts industriels variaient de 17,55 $\pm 1,63$ à $80,99 \pm 2,61 \mathrm{~Bq} \mathrm{~kg}^{-1}$ pour le ${ }^{226} \mathrm{Ra}$, de $7,64 \pm 0,77$ à $23,94 \pm 0,92 \mathrm{~Bq} \cdot \mathrm{kg}^{-1}$ pour le ${ }^{232}$ Th et de $63,22 \pm 3,43$ à $503,90 \pm 5,69 \mathrm{~Bq} \cdot \mathrm{kg}^{-1}$ pour le ${ }^{40} \mathrm{~K}$ alors que dans les échantillons de sol, ce niveau variait de 2,87 à $34,78 \mathrm{~Bq} . \mathrm{kg}^{-1}$, de 7,02 à $24,47 \mathrm{~Bq} \cdot \mathrm{kg}^{-1}$ et de 7,05 à $162,81 \mathrm{~Bq} . \mathrm{kg}^{-1}$, respectivement pour le ${ }^{226} \mathrm{Ra}$, le ${ }^{232} \mathrm{Th}$ et le ${ }^{40} \mathrm{~K}$. Ces résultats sont présentés ainsi que les estimations des débits de dose absorbée, les débits de dose effective annuelle, la dose équivalente en radium $\left(R a_{e q}\right)$, l'indice de détriment externe $\left(H_{e x}\right)$, l'indice de

\footnotetext{
1 Radiation and Health Physics Research Laboratory, Department of Physics, University of Ibadan, Ibadan, Nigeria.
} 
détriment interne $\left(H_{i n}\right)$ et une représentation de l'indice d'exposition aux radiations gamma $\left(I_{\gamma_{r}}\right)$. Les résultats obtenus sont inférieurs aux limites de sûreté internationalement acceptées. De ce fait, les échantillons analysés peuvent être utilisés par l'industrie locale comme matières premières et/ou comme matériaux de construction. De plus, les activités minières locales produisant ces minéraux n'affectent pas de façon significative les niveaux de dose de radiation naturelle dans la région, et par conséquent la dose résultante à la population est ainsi considérée comme généralement basse.

\section{Introduction}

The radionuclides in mineral soil generate a significant component of the background radiation exposure to the population (Goddard, 2002). The environmental effect of radiation from mineral resources depends on the use of the raw material or end product of such minerals in the environment. Kaolin and the clay mineral kaolinite are natural components of the soil and occur widely in ambient air as floating dust. Kaolinite is formed mainly by decomposition of feldspars (potassium feldspars), granite and aluminum silicates. It is also not uncommon to find kaolin deposited together with other minerals (illite, bentonite) (Grim, 1968). Clay is a widely distributed, abundant mineral resource of major industrial importance for an enormous variety of uses (Ampian, 1985). Illite is widely distributed in nature, abundant, and often the dominant clay mineral in soil, terrestrial deposits, sedimentary rocks, freshwater sediments, and most deep-sea clays (Grim, 1968). Kaolin and common clay may contain varying amounts of silica; a short summary is presented in recent assessments of quartz (IARC, 1997a, b).

Owing to inherently complex physical, chemical and mineralogical characteristics, clays are used mainly in the manufacture of bricks, portland and other cements, concrete blocks and structural concrete, and refractory and ceramics (electrical porcelain, fine china and dinnerware, floor and wall tiles, and pottery). These minerals, especially clay, are used in construction of dwellings by local residents in Akwa Ibom State of Nigeria.

Due to the health risks associated with the exposure to indoor radiation, many governmental and international bodies such as the International Commission on Radiological Protection (ICRP), the World Health Organization (WHO), etc. have adopted strong measures aimed at minimizing such exposures. This is imperative because the most significant exposure as regards the radiation health burden is due to the isotopes of radon $\left({ }^{222} \mathrm{Rn}\right.$ and $\left.{ }^{220} \mathrm{Rn}\right)$. They are the decay products of radium $\left({ }^{226} \mathrm{Ra}\right.$ and $\left.{ }^{224} \mathrm{Ra}\right)$ and are the members of the decay series of ${ }^{238} \mathrm{U}$ and ${ }^{232} \mathrm{Th}$, respectively. Radon and its short-lived daughters are alpha emitters. They consequently become a major source of internal exposure of the respiratory tracts 
when inhaled (IPCS, 2000; Stoulos et al., 2003; Ferdoes et al., 2007), hence the call for the measurement and assessment of natural radionuclides in industrial raw minerals and construction materials worldwide (Stoulos et al., 2003; Turhan Seref, 2009; Ferdoes et al.,2007; Chang et al., 2008; Abel-Ghany et al., 2009).

In Nigeria there is a concerted effort towards determining the radionuclide concentration levels in different raw mineral and building materials (Farai and Ademola, 2001; Ademola, 2005; Ademola et al., 2008; Obed et al., 2005) and industrial wastes and by-products from some industries (Jibiri and Adewuyi, 2008; Farai et al., 2009). It has not been possible to carry out a nationwide survey of these materials because of logistics and financial set-backs. However, most radioactivity studies in building and raw materials have remained localized and it is envisaged that a compilation of these results from different regions will generate the overall requisite information on building materials with a potential radiological impact on human population in Nigeria.

This present study was designed to add to and enhance the existing information on radioactivity contents from different building materials in Nigeria with particular interest in Akwa Ibom State in the South-South region of the country. Presently, there is no data existing on the concentration of these natural radionuclides in minerals used for industrial raw minerals and construction purposes in the state, especially for the industrial raw minerals considered in this study.

The knowledge of radiation levels in the environment is imperative; hence this study is expected to yield data that will provide information that may be used to assess the health effects on the population due to the usage of the final products from these minerals, and also terrestrial radiation exposure around these mining sites. The objectives of the present study are to: (i) determine the activity concentrations of ${ }^{226} \mathrm{Ra},{ }^{232} \mathrm{Th}$ and ${ }^{40} \mathrm{~K}$ in industrial raw minerals and soil samples at the mining sites of industries in Akwa Ibom; (ii) determine radiological hazard indices such as radium equivalent activity $\left(R a_{e q}\right)$, absorbed gamma dose rate $(D)$, the external $\left(H_{e x}\right)$, internal $\left(H_{i n}\right)$ and the representative gamma $\left(I_{y r}\right)$, (iii) provide radiometric data that may be useful in future epidemiological studies, and (iv) provide information that will enhance the radioactivity data of the Nigerian environment.

\section{Materials and methods}

\subsection{Sample collection}

Akwa Ibom State lies between latitudes $4^{\circ} 32^{\prime}$ and $5^{\circ} 33^{\prime}$ North; and longitudes $7^{\circ} 25^{\prime}$ and $8^{\circ} 25^{\prime}$ East. The landscape of Akwa Ibom is mostly flat. This is because the underlying geology of the state is predominantly coastal plain sediments. The 
TABLE I

Industrial raw minerals and number of samples collected. Les minéraux bruts industriels et le nombre d'échantillons récoltés.

\begin{tabular}{|c|c|c|c|c|}
\hline Sample code & Name of raw mineral & No. of mineral samples & No. of soil samples & Industries \\
\hline $\mathrm{Rm}_{1}$ & Kyanite & 1 & - & Q.C* \\
\hline $\mathrm{Rm}_{2}$ & Laterite & 1 & 15 & Q.C* \\
\hline $\mathrm{Rm}_{3}$ & Kaoline & 1 & 15 & Q.C* \\
\hline $\mathrm{Rm}_{4}$ & Kaolinitic clay & 1 & - & Pot. Ind. \\
\hline $\mathrm{Rm}_{5}$ & Illite (Common clay) & 1 & - & Pot. Ind. \\
\hline $\mathrm{Rm}_{6}$ & Silica sand & 1 & 15 & Q.C*' \\
\hline
\end{tabular}

coastal nature of the state makes it the natural deposit of a mosaic of marine, deltaic, estuarine, lagoonal and fluvio-lacustrine material. This favors the large expanse of deposits of mineral sources such as kaolin, kalonite, illite, etc. in the area, and extensive mining activities. Pottery, quality ceramics and smelting industries amongst others are widespread across the state. There are three major mining sites in the state; kaolin, laterite and silica sand, and they belong to the quality ceramics/smelting and pottery industries.

About six domestically produced industrial raw minerals, and fifteen samples of soil at each of the three mining sites were collected and also from the immediate communities at relatively different distances from these mining sites. The domestic minerals were sampled directly by visiting the mine sites. These are samples that may likely find their way into the environment and consequently contaminate it. This was considered important so that spatial radionuclide concentration levels could be obtained for the assessment of the likely operational effects of the activities of the industries on the immediate environment and the population. The soil samples and the raw materials were collected into labeled polythene bags and were transferred to the Radiation and Health Physics Research Laboratory, University of Ibadan, for gamma-ray analysis. The sample types and the number of each type that was collected are presented in Table I.

\subsection{Sample preparation}

The collected samples were pulverized and sieved through a $0.2 \mathrm{~mm}$ mesh with a crusher and ceramic mortar, and then homogenized to obtain the same structural matrix after which, a mass of $200 \mathrm{~g}$ each was weighed using a Scout Pro weight machine by Ohaus with precision of $0.1 \mathrm{~g}$. The powdered samples were transferred to cylindrical screw cap plastic containers of dimensions $6.8 \mathrm{~cm} \times 7.3 \mathrm{~cm}$ and 
sealed tightly with covers using masking/transparent tape to prevent the escape of

${ }^{222} \mathrm{Rn}$, the daughter of ${ }^{226} \mathrm{Ra}$. The sealed samples were weighed and kept for more than 5 weeks so as to re-establish secular equilibrium between radium isotopes and their progenies following sample collection and preparation procedures.

The detector used for the radioactivity measurements was a $10 \mathrm{~cm}$ leadshielded $76 \mathrm{~mm} \times 76 \mathrm{~mm} \mathrm{NaI(Tl)}$ detector crystal (802 series Canberra Inc.) coupled to a Canberra Series 10 plus Multichannel Analyzer (MCA - Model: 1105 ) through a preamplifier. It has a resolution (full weight at half maximum FWHM) of about $8 \%$ at energy of $0.662 \mathrm{MeV}$ for ${ }^{137} \mathrm{Cs}$ which is considered adequate to distinguish the gamma-ray energies of interest in this study. The choice of radionuclide to be detected was predicated on the fact that the $\mathrm{NaI}(\mathrm{Tl})$ detector used in this study has high efficiency.

\subsection{Energy calibration}

The purpose of calibration is to determine, under a controlled set of standard conditions, the indication of an instrument as a function of the value of the measured (the quantity intended to be measured) and this was carried out over the complete range of indications of the system. The calibration of the detector to determine the equation relating energy to channel number was carried out by placing different gamma sources of known energies from Nucleus Inc., Oak Ridge, USA, of IAEA EMS calibrated gamma sources and Geological Certified Reference Material from Radiometric Measurement from the International Atomic Energy Agency (IAEA), Vienna. The gamma sources were placed on the detector at a distance $7 \mathrm{~cm}$ from the surface of the detector. After a preset counting time of $100 \mathrm{~s}$, the channels of the various photopeaks corresponding to the gamma energies were identified. This was done for the purpose of identifying the various radionuclides that may be present in the sample through the energies they emit.

\subsection{Detection efficiency calibration}

The second stage in the calibration process was the determination of the gammaray counting efficiencies over the energy range $0.511-2.615 \mathrm{MeV}$. This was done by converting the count per second (cps) under the photopeaks to the activity concentration $\left(\mathrm{Bq}_{\mathrm{kg}}{ }^{-1}\right)$ of certified reference standard samples. The standard gamma source was prepared by Rocketdyne Laboratories, Canoga Park, California, USA. This is traceable to a mixed standard gamma source (ENV94084 - $200 \mathrm{~g}$ ) by Analytics Inc., Atlanta, Georgia (USA). The certified standard sources have activity concentrations of $479.15 \mathrm{~Bq} \cdot \mathrm{kg}^{-1} \pm 4.89 \%, 566.47 \mathrm{~Bq} \cdot \mathrm{kg}^{-1} \pm 1.47 \%$ and $11.60 \mathrm{~Bq} \cdot \mathrm{kg}^{-1} \pm 6.61 \%$ for ${ }^{40} \mathrm{~K},{ }^{226} \mathrm{Ra}$ and ${ }^{232} \mathrm{Th}$, respectively. The reference standard source was placed symmetrically on top of the detector and counted for 
TABLE II

Activity concentrations of ${ }^{40} \mathrm{~K},{ }^{238} \mathrm{U}$ and ${ }^{232} \mathrm{Th}\left(\mathrm{Bq} \cdot \mathrm{kg}^{-1}\right)$ of the industrial raw mineral samples. Concentration en ${ }^{40} \mathrm{~K},{ }^{238} \mathrm{U}$ et ${ }^{232} \mathrm{Th}\left(\mathrm{Bq}^{2} \cdot \mathrm{kg}^{-1}\right)$ dans les échantillons de minéraux bruts industriels.

\begin{tabular}{lccc}
\hline \multirow{2}{*}{$\begin{array}{l}\text { Industrial raw } \\
\text { minerals }\end{array}$} & \multicolumn{3}{c}{ Activity concentration $\left(\mathbf{B q . \mathbf { k g } ^ { - \mathbf { 1 } } )}\right.$} \\
\cline { 2 - 4 } & ${ }^{\mathbf{4 0}} \mathbf{K}$ & ${ }^{\mathbf{2 3 8}} \mathbf{U}$ & ${ }^{\mathbf{2 3 2} \mathbf{T h}}$ \\
\hline Kyanite & $195.85 \pm 4.23$ & $25.42 \pm 1.76$ & $7.64 \pm 0.77$ \\
Laterite & $63.22 \pm 3.43$ & $28.86 \pm 1.82$ & $22.5 \pm 0.91$ \\
Kaolin & $496.18 \pm 5.64$ & $80.99 \pm 2.61$ & $8.82 \pm 0.78$ \\
Kaolinite & $72.05 \pm 3.48$ & $65.72 \pm 2.41$ & $23.07 \pm 0.90$ \\
\hline Illite & $503.9 \pm 5.69$ & $36.66 \pm 1.95$ & $23.94 \pm 0.92$ \\
Silica sand & $81.03 \pm 3.53$ & $17.55 \pm 1.63$ & $16.28 \pm 0.86$ \\
\hline
\end{tabular}

$36000 \mathrm{~s}(10 \mathrm{~h})$ after which the counting efficiencies $E_{p}$ at different gammaenergies were determined using equation (1) (Farai and Ademola, 2001; Ademola, 2005):

$$
E_{p}=\frac{A_{n e t}}{T_{s} C \gamma M_{s}}
$$

where $A_{n e t}$ is the net area under the photopeak of each radionuclide, $C$ is the activity concentration of each radionuclide in the standard reference source, $T_{S}$ is the counting time in $\mathrm{s}, \gamma$ is the gamma yield (a fraction of the gamma rays of the particular energy per disintegration) and $M_{S}$ is the mass of the sample.

\section{Results and discussion}

\subsection{Activity concentrations of the industrial raw minerals and soil samples}

From the gamma spectrometric analysis, three naturally occurring radionuclides were detected and measured. The obtained values of the measured activity concentrations of ${ }^{226} \mathrm{Ra},{ }^{232} \mathrm{Th}$ and ${ }^{40} \mathrm{~K}$ in the industrial raw mineral samples are presented in Table II. As can be seen from the table, the concentrations varied for ${ }^{226} \mathrm{Ra}(17.55 \pm 1.63-80.99 \pm 2.61) \mathrm{Bq} \cdot \mathrm{kg}^{-1},{ }^{232} \mathrm{Th}(7.64 \pm 0.77-23.94 \pm 0.92)$ Bq. $\mathrm{kg}^{-1}$ and ${ }^{40} \mathrm{~K}(63.22 \pm 3.43-503.90 \pm 5.69) \mathrm{Bq} \cdot \mathrm{kg}^{-1}$. Also, ${ }^{40} \mathrm{~K}$ and ${ }^{232} \mathrm{Th}$ were found to be high in illite clay $\left(\mathrm{Rm}_{5}\right)$ with activity concentrations of $503.92 \pm$ $5.69 \mathrm{~Bq} \cdot \mathrm{kg}^{-1}$ and $23.94 \pm 0.92 \mathrm{~Bq} \cdot \mathrm{kg}^{-1}$, respectively, while kaolin $\left(\mathrm{Rm}_{3}\right)$ had the 


\section{TABLE III}

The range and mean of the activity concentrations of the radionuclides and the absorbed dose rate in air at the three mining sites $(\mathrm{A}, \mathrm{B} \& \mathrm{C})$.

Domaine de variation et moyenne des concentrations en radionucléides et du débit de dose absorbée dans l'air des trois sites miniers (A, B \& C).

\begin{tabular}{|c|c|c|c|c|c|c|c|c|}
\hline \multirow[t]{2}{*}{ Sites } & \multicolumn{2}{|c|}{${ }^{40} K\left(\right.$ Bq.kg $\left.{ }^{-1}\right)$} & \multicolumn{2}{|c|}{${ }^{226} \mathrm{Ra}\left(\mathrm{Bq} \cdot \mathrm{kg}^{-1}\right)$} & \multicolumn{2}{|c|}{${ }^{232}$ Th $\left(\mathrm{Bq} \cdot \mathrm{kg}^{-1}\right)$} & \multicolumn{2}{|c|}{$\begin{array}{c}\text { Total absorbed dose rate } \\
\left(\mathrm{nGy} \cdot \mathrm{y}^{-1}\right)\end{array}$} \\
\hline & Range & Mean \pm SD $^{*}$ & Range & Mean \pm SD* & Range & Mean \pm SD* & Range & Mean \pm SD* \\
\hline $\begin{array}{l}\text { Kaolin } \\
\text { (A) }\end{array}$ & $7.05-58.09$ & $27.75 \pm 3.90$ & $2.87-26.91$ & $16.32 \pm 1.47$ & $8.34-18.78$ & $15.43 \pm 0.75$ & $13.92-22.77$ & $18.14 \pm 2.19$ \\
\hline $\begin{array}{l}\text { Laterite } \\
\text { (B) }\end{array}$ & $53.29-162.81$ & $102.80 \pm 7.35$ & $10.53-26.72$ & $19.45 \pm 1.69$ & $9.66-24.47$ & $17.32 \pm 0.74$ & $17.73-30.00$ & $23.37 \pm 3.79$ \\
\hline $\begin{array}{l}\text { Silica } \\
\text { sand (C) }\end{array}$ & $13.49-78.21$ & $48.49 \pm 4.39$ & $7.54-34.78$ & $20.65 \pm 1.96$ & $7.02-21.56$ & $16.72 \pm 1.06$ & $1.69-5.03$ & $3.51 \pm 0.25$ \\
\hline
\end{tabular}

highest measured value of ${ }^{226} \mathrm{Ra}$, with an activity concentration of $80.99 \pm$ $2.60 \mathrm{~Bq} \cdot \mathrm{kg}^{-1}$. The activity concentrations of the radionuclides in this study are comparable with the values in concrete blocks in Ibadan, Nigeria (Farai and Ademola, 2001), but lower than those determined for granite samples in Ondo State (Ademola and Ayeni, 2010).

Similarly, from the measured gamma-ray spectra of ${ }^{226} \mathrm{Ra},{ }^{232} \mathrm{Th}$ and ${ }^{40} \mathrm{~K}$, activity concentrations of the soil samples were determined for the three mining sites (A, B and C). The range and mean of the activity concentrations are presented in Table III. From the results obtained, ${ }^{226} \mathrm{Ra}$ and ${ }^{232} \mathrm{Th}$ have the highest activity concentrations of $34.78 \pm 1.95$ and $21.56 \pm 0.93 \mathrm{~Bq} \cdot \mathrm{kg}^{-1}$, respectively, which are high when compared with the values obtained by Ademola et al. (2008) in Igbeti, Nigeria, which has a similar sedimentary formation to the study area region. The variation and similarities are in agreement with previous studies that terrestrial radioactivity to a large extent depends on the local geology and other related factors in the environment (Wollenberg and Smith, 1990). According to Orabi et al. (2006) and Al-Jundia et al. (2003), the concentrations of these radionuclides in soil are determined by the radioactivity of the rock and also the nature of the process of the formation of the soils.

\subsection{Determination of radiation hazard indices}

\subsubsection{Assessment of radium equivalent activity in the industrial raw minerals and soil samples}

To represent the activity levels of ${ }^{226} \mathrm{Ra},{ }^{232} \mathrm{Th}$ and ${ }^{40} \mathrm{~K}$ by a single quantity, which takes into account the radiation hazards associated with them, a common 


\section{TABLE IV}

Radium equivalent $\mathrm{Ra}_{\mathrm{eq}}\left(\mathrm{Bq} \cdot \mathrm{kg}^{-1}\right)$, external $\left(H_{e x}\right)$ and internal $\left(H_{i n}\right)$ radiation exposure and gamma index $\left(I_{\gamma r}\right)$ of industrial raw mineral samples.

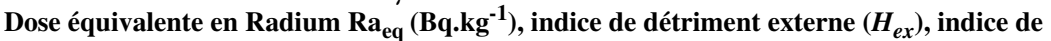
détriment interne $\left(H_{i n}\right)$ et indice d'exposition aux radiations gamma $\left(I_{\gamma_{r}}\right)$ des échantillons de minéraux bruts industriels.

\begin{tabular}{lcccc}
\hline $\begin{array}{l}\text { Industrial raw } \\
\text { minerals }\end{array}$ & $\boldsymbol{R a}_{\boldsymbol{e q}}\left(\mathbf{B q . \mathbf { k g } ^ { - \mathbf { 1 } } )}\right.$ & $\boldsymbol{H}_{\boldsymbol{e x}}$ & $\boldsymbol{H}_{\boldsymbol{i n}}$ & $\boldsymbol{I}_{\boldsymbol{\gamma} \boldsymbol{r}}$ \\
\hline Kyanite & 51.43 & 0.14 & 0.21 & 0.38 \\
Laterite & 65.90 & 0.17 & 0.26 & 0.49 \\
Kaolin & 131.81 & 0.36 & 0.57 & 0.96 \\
Kaolinitic clay & 104.25 & 0.28 & 0.46 & 0.72 \\
Illite (clay) & 109.69 & 0.30 & 0.39 & 0.82 \\
Silica sand & 38.55 & 0.10 & 0.15 & 0.27 \\
\hline
\end{tabular}

radiological index has been introduced. This index is called radium equivalent $\left(\mathrm{Ra}_{\mathrm{eq}}\right)$ activity and is expressed mathematically by UNSCEAR (2000):

$$
R a_{e q}\left(\mathrm{~Bq} \cdot \mathrm{kg}^{-1}\right)=A_{R a}+1.43 A_{t h}+0.077 A_{k}
$$

where $A_{R a}, A_{T h}$ and $A_{K}$ are the activity concentrations of ${ }^{226} \mathrm{Ra},{ }^{232} \mathrm{Th}$ and ${ }^{40} \mathrm{~K}$, respectively.

It may be noted that ${ }^{238} \mathrm{U}$ was replaced with the decay product ${ }^{226} \mathrm{R}_{\mathrm{a}}$ because there may be disequilibrium between ${ }^{238} \mathrm{U}$ and ${ }^{226} \mathrm{Ra}$. The maximum permissible value of the radium equivalent activity is $370 \mathrm{~Bq}^{\mathrm{kg}} \mathrm{kg}^{-1}$ (UNSCEAR, 1982): this evaluation will assist in determining if soil from the study area could be used for building of residential houses. In the above relation (Eq. (2)), it has been assumed that $10 \mathrm{~Bq} \cdot \mathrm{kg}^{-1}$ of ${ }^{226} \mathrm{Ra}, 7 \mathrm{~Bq} \cdot \mathrm{kg}^{-1}$ of ${ }^{232} \mathrm{Th}$ and $130 \mathrm{~Bq} \cdot \mathrm{kg}^{-1}$ of ${ }^{40} \mathrm{~K}$ produce an equal gamma dose (Beretka and Mathew, 1985). The results of the radium equivalent obtained are presented in Table IV. Similarly, from equation (2) the radium equivalent activity of the collected soil samples for the three sites were obtained. These are presented in Table V. The values varied as follows; for Site A (kaolin) (30.47-50.15 Bq. $\mathrm{kg}^{-1}$ ) with a mean value of $40.01 \pm 1.22 \mathrm{~Bq} \cdot \mathrm{kg}^{-1}$; Site B (laterite) (38.78-64.69 Bq. kg $\left.{ }^{-1}\right)$ with a mean value of $49.67 \pm 3.51 \mathrm{~Bq} \cdot \mathrm{kg}^{-1}$ and Site $\mathrm{C}$ (silica sand) (25.15-68.83 Bq. kg ${ }^{-1}$ ) with a mean value of $46.66 \pm 2.83 \mathrm{~Bq} \cdot \mathrm{kg}^{-1}$. These values are below the maximum permissible value of $370 \mathrm{~Bq} \cdot \mathrm{kg}^{-1}$ (UNSCEAR, 2000).

\subsubsection{Determination of gamma absorbed dose rate in air}

The absorbed dose rates $(D)$ due to gamma radiation in air at $1 \mathrm{~m}$ above the ground surface for the uniform distribution of the naturally occurring radionuclides 


\section{TABLE V}

The range and mean of the Radium equivalent dose $R a_{e q}\left(\mathrm{~Bq}_{\mathrm{kg}} \mathrm{g}^{-1}\right)$, and external $\left(H_{e x}\right)$, internal $\left(H_{i n}\right)$ and gamma $\left(I_{\gamma r}\right)$ radiation exposure of soil samples at the three sites.

Domaine de variation et moyenne de la dose équivalente en $\operatorname{Radium} R a_{e q}\left(\mathrm{~Bq}_{\mathrm{kgg}}{ }^{-1}\right)$, de l'indice de détriment externe $\left(H_{e x}\right)$, de l'indice de détriment interne $\left(H_{i n}\right)$ et de l'indice d'exposition aux radiations gamma $\left(I_{\gamma r}\right)$ des échantillons de sol des trois sites.

\begin{tabular}{ccccc}
\hline $\begin{array}{c}\text { Sample } \\
\text { locations }\end{array}$ & $\boldsymbol{R a}_{\boldsymbol{e q}\left(\mathrm{Bq} \cdot \mathrm{kg}^{-1}\right)}$ & $\boldsymbol{H}_{\boldsymbol{e x}}$ & $\boldsymbol{H}_{\boldsymbol{i n}}$ & $\boldsymbol{I}_{\boldsymbol{\gamma} \boldsymbol{r}}$ \\
\cline { 2 - 5 } & $\begin{array}{c}\text { Range } \\
\text { mean }\end{array}$ & $\begin{array}{c}\text { Range } \\
\text { mean }\end{array}$ & $\begin{array}{c}\text { Range } \\
\text { mean }\end{array}$ & $\begin{array}{c}\text { Range } \\
\text { mean }\end{array}$ \\
\hline Site A & $30.47-50.15$ & $0.01-0.14$ & $0.11-0.20$ & $0.21-0.37$ \\
& $40.01 \pm 4.88$ & 0.12 & 0.18 & 0.29 \\
Site B & $38.78-64.69$ & $0.11-018$ & $0.14-0.24$ & $0.27-0.46$ \\
& $49.67 \pm 7.51$ & 0.13 & 0.19 & 0.38 \\
Site C & $25.15-68.83$ & $0.09-0.19$ & $0.12-0.28$ & $0.18-0.48$ \\
& $46.66 \pm 11.36$ & 0.13 & 0.15 & 0.33 \\
\hline
\end{tabular}

$\left({ }^{226} \mathrm{Ra},{ }^{232} \mathrm{Th}\right.$ and $\left.{ }^{40} \mathrm{~K}\right)$ were calculated based on guidelines provided by UNSCEAR (2000). We assumed that the contributions from other naturally occurring radionuclides were insignificant. Hence, $D$ can be calculated according to UNSCEAR (2000) as:

$$
D\left(\mathrm{nGy} \cdot \mathrm{h}^{-1}\right)=0.462 A_{R a}+0.621 A_{T h}+0.0417 A_{k} .
$$

The absorbed dose rate in air for the collected soil samples was calculated for the three sites (A, B and C) using equation (3). The range and mean results are also presented in Table III. The highest average absorbed dose of $23.37 \pm 3.79 \mathrm{nGy} \cdot \mathrm{h}^{-1}$ was obtained at site B (laterite) and the lowest average of $3.51 \pm 0.25 \mathrm{nGy} \cdot \mathrm{h}^{-1}$ at site C (silica sand). All these values are lower than the world average outdoor terrestrial dose value of $55 \mathrm{nGy} \cdot \mathrm{h}^{-1}$ (UNSCEAR, 2000).

\subsubsection{Assessment of annual effective dose rate in air}

The absorbed gamma dose rates in air are more often related to the human gamma dose in order to assess the effectiveness of the gamma dose in causing damage to human tissues. Damage to the tissues may result in somatic and genetic health effects. To estimate the annual effective dose rates, the conversion coefficient from the absorbed dose in air to the effective dose $\left(0.7 \mathrm{~Sv}^{\left.-G_{y}{ }^{-1}\right)}\right.$ and the outdoor occupancy factor (0.2) proposed by UNSCEAR (2000) are used. Therefore, the annual effective dose rate $\left(\mathrm{mSv}_{\mathrm{yr}}{ }^{-1}\right)$ was calculated using the formula (Jibiri and Adewuyi, 2008; Jibiri and Emelue, 2008)

$$
E_{\text {air }}=T f Q D_{\text {air }} \xi
$$

where $E_{\text {air }}$ is the effective dose rate $\left(\mathrm{mSv}^{-1} \mathrm{y}^{-1}\right), T$ is the time, $\mathrm{f}$ is the outdoor occupancy factor which corrects for the average time spent outdoors $(0.2), Q$ is the 
quotient of the effective dose rate and absorbed dose rate in air $\left(0.7 \mathrm{~Sv}^{-\mathrm{Gy}^{-1}}\right)$, $\xi$ is the factor converting nano $\left(10^{-9}\right)$ into milli $\left(10^{-3}\right)$; and $D_{\text {air }}$ is the absorbed dose rate in air $\left(\mathrm{nGy} \cdot \mathrm{h}^{-1}\right)$. Using the total absorbed dose rate values from equation (4), the baseline annual effective dose was calculated using the mean total absorbed dose in Table II. From the results obtained, the effective dose rate in air for the three sites (A, B and C) ranged from $0.0043-0.0293 \mathrm{mSv}_{\mathrm{yr}}{ }^{-1}$ with a mean value of $0.02 \mathrm{mSv} \cdot \mathrm{yr}^{-1}\left(20 \mu \mathrm{Sv} . \mathrm{y}^{-1}\right)$. These values were below the prescribed limits, since the acceptable dose equivalent for the public is $1 \mathrm{mSv} \cdot \mathrm{y}^{-1}$, or $20 \mathrm{mSv}^{-1} \mathrm{y}^{-1}$ for radiation workers (ICRP, 1991).

\subsubsection{External hazard index $\left(H_{e x}\right)$}

An extensively used hazard index (reflecting the external exposure) called the external hazard index $H_{e x}$ is defined by (UNSCEAR, 2000):

$$
H_{e x}=\frac{A_{R a}}{370}+\frac{A_{T h}}{259}+\frac{A_{k}}{4810} .
$$

The external index for the industrial raw minerals was calculated using equation (5): the results are presented in Table IV. The values varied from 0.07 to 0.36 with a mean value of 0.22 . Similarly, the external hazard index of the collected soil samples was also calculated using equation (5) and the results are presented in Table V. The values obtained ranged for Site A from (0.01-0.14); Site B (0.11-0.18) and Site C (0.09-0.19).

\subsubsection{Internal hazard index $\left(H_{i n}\right)$ for the raw minerals}

In addition to the external hazard index, radon and its short-lived products are also hazardous to the respiratory organs. Internal exposure to radon and its daughter products is quantified by the internal hazard index $H_{i n}$, which is given by Beretka and Mathew (1985) in equation (6):

$$
H_{i n}=\frac{A_{R a}}{185}+\frac{A_{T h}}{259}+\frac{A_{k}}{4810} .
$$

The values of the indices $\left(H_{e x}, H_{i n}\right)$ must be less than unity for the radiation hazard to be negligible (Beretka and Mathew, 1985). The internal index $\left(H_{e x}\right)$ for the industrial raw minerals was calculated using equation (6): the values varied from 0.15 to 0.57 with a mean value of 0.37 . These values are also presented in Table IV.

Similarly, the internal index of the collected soil samples was also calculated for the three sites (A, B and C). The results obtained are presented in Table V. The 
values ranged for site A from (0.11-0.20); site B (0.14-0.24) and site $\mathrm{C}(0.12-0.28)$. It is clear that the results obtained were below the criterion of unity (UNSCEAR, 2000).

\subsubsection{Gamma index $\left(I_{\gamma}\right)$ for the raw mineral samples}

According to the European Commission (1999), the following gamma activity concentration index $\left(I_{\gamma}\right)$ (representative level index) is derived for identifying whether a dose criterion is met:

$$
I_{\gamma r}=\frac{A_{R a}}{150}+\frac{A_{T h}}{100}+\frac{A_{k}}{1500} .
$$

The index $I_{\gamma}$ is correlated with the annual dose due to the excess external gamma radiation caused by superficial material. Values of index $I \leq 1$ correspond to $0.3 \mathrm{mSv} / \mathrm{y}^{-1}$, while values of $I \leq 3$ correspond to $1 \mathrm{mSv} / \mathrm{y}^{-1}$ (EC, 1999). Gamma index $\left(I_{\gamma}\right)$ radiation exposure was calculated from equation (7): the results are presented in Table IV. The results ranged from 0.27 to 0.96 with a mean value of 0.61 . These values are below the criterion of unity corresponding to an annual effective dose of $0.3 \mathrm{mSv}$ (EC, 1999).

Again, the gamma index of the collected soil samples for the three sites was calculated and the results obtained are also presented in Table $\mathrm{V}$. The values, as can be seen from the table, ranged for site A from (0.21-0.37); site B (0.27-0.46) and site $\mathrm{C}(0.18-0.48)$. The range of values for the external, internal and gamma indices obtained for the soil samples were below the criterion of unity corresponding to an annual effective dose of $0.3 \mathrm{mSv}_{\mathrm{yr}} \mathrm{r}^{-1}$ (EC, 1999). Hence, the use of soil samples as building material is seen not to pose any significant radiation hazard to the population in the study area.

\section{Conclusion}

In view of worldwide concern about the radionuclide contents of various industrial raw materials, radiological assessment of the activity concentrations of different industrial raw minerals (kaolin, illite, kyanite, laterite and silica sand) in Akwa Ibom State, South-South Nigeria, were carried out. From the results obtained, the total absorbed dose rate in air due to soil samples for the three sites ranged from 1.69 to $30.00 \mathrm{nGy} \cdot \mathrm{h}^{-1}$ with a mean of $18.14 \pm 2.19 \mathrm{nGy} \cdot \mathrm{h}^{-1}$. This corresponds to an annual effective dose range of $0.0043-0.0293 \mathrm{mSv}^{-1} \mathrm{y}^{-1}$. These values and other radiological indices such as the radium equivalent, and internal, external and representative gamma indices estimated for the soil and raw mineral samples were found to be below the prescribed safe limits. Therefore, use of these samples in the 
local industries as component raw materials or as building materials for dwellings is seen not to pose any significant radiation health hazard to the population in the study area. Also, the mining activities of these minerals in the area have not significantly affected the natural radiation dose levels in the area.

\section{REFERENCES}

Abel-Ghany H.A, El-Zakla T., Hassan A.M. (2009) Environmental Radioactivity Measurement of some Egyptian sand samples, Rom. J. Phys. 54, 213-223.

Ademola J.A. (2005) Radionuclide content of concrete building blocks and radiation dose rates in some dwellings in Ibadan, Nigeria, J. Environ. Radioact. 81, 107-113.

Ademola J.A., Ayeni A.A. (2010) Measurement of natural radionuclides and dose assessment of granites from Ondo State, Nigeria, Radioprotection 45, 515-521.

Ademola J.A., Hammed O.S., Adejumobi C. A. (2008) Radioactivity and dose Assessment of Marble Samples from Igbeti Mines, Nigeria, J. Radiat. Prot. Dosim., doi:10.1093/rpd/ncn279.

Al-Jundia J., Al-Bataina B.A., Abu-Rukah Y., Shehadeh H.M. (2003) Natural radioactivity concentrations in soil samples along the Amman Aqaba Highway, Jordan, Radiat. Meas. 36, 555-560.

Ampian S.G (1985) Clays. In: Mineral facts and problems. Washington, DC, US Bureau of Mines, pp. 1-13 (Bulletin 675).

Beretka J., Mathew P.J. (1985) Natural radioactivity of Australian building materials, industrial wastes and by-products, Health Phys. 48, 87-95.

Chang B.U., Koh S.M., Kim Y.J., Seo J.S., Yoon Y.Y., Row J.W., Lee D.M. (2008) Nationwide survey on the natural radionuclides in industrial raw materials in South Korea, J. Environ. Radioact. 99, 455-460.

European Commission (EC) (1999) European Commission Report on Radiological Protection Principles Concerning the Natural Radioactivity of Building Materials', Radiat. Prot. 112.

Farai I.P., Ademola J.A. (2001) Population dose due to building materials in Ibadan, Nigeria, Radiat. Prot. Dosim. 95, 69-73.

Farai I.P., Adewole O.O., Isinkaye M.O., Jibiri N.N. (2009) Radiological effects of some industrial wastes and by-products generated in Lagos, Nigeria, J. Fiz. Malaysia 30, 43-48.

Ferdoes S., Al-Salel, Badriah, Al-Berzan (2007) Measurements of Natural Radioactivity in some kind of marble and granite used in Riyadh region, J. Nucl. Radiat. Phys. 2, 25-36.

Goddard C.C. (2002) Measurement of outdoor terrestrial gamma radiation in the Sultanate of Oman, Health Phys. 82, 869-874.

Grim R.E. (1968) Clay mineralogy. 2nd ed. New York, McGraw-Hill, p. 596.

International Agency for Research on Cancer (IARC) (1997a) Silica. In: Silica, some silicates, coal dust and para-aramid fibrils. Lyon, International Agency for Research on Cancer (IARC) Monographs on the Evaluation of Carcinogenic Risks to Humans, Vol. 68, pp. 241-242.

International Agency for Research on Cancer (IARC) (1997b) Palygorskite (attapulgite). In: Silica, some silicates, coal dust and para-aramid fibrils. Lyon, International Agency for Research on Cancer (IARC) Monographs on the Evaluation of Carcinogenic Risks to Humans, Vol. 68, pp. 245-255.

ICRP Publication 60 (1991) 1990 Recommendations of the International Commission on Radiological Protection, Ann. ICRP 21, 1-3.

International Programme on Chemical Safety (IPCS) (2000) Crystalline silica, quartz. Geneva, World Health Organization, International Programme on Chemical Safety, p. 55 (Concise International Chemical Assessment Document 24). 
Jibiri N.N., Emelue H.U. (2008) Soil radionuclide concentration and radiological assessment in and around a refining and petrochemical company in Warri, Niger Delta, Nigeria, J. Radiol. Prot. 28, 361-368.

Jibiri N.N., Adewuyi G.O. (2008) Radionuclide contents and physico-chemical characterization of soild waste and effluent samples of some selected industries in the city of Lagos, Nigeria, Radioprotection 43, 203-212.

Obed R.I., Farai I.P., Jibiri N.N. (2005) Population dose distribution due to soil radioactivity concentration levels in 18 cities across Nigeria, J. Radiol. Prot. 25, 305-312.

Orabi H., Al-Shareaif A., El Galefi M. (2006) Gamma-ray measurements of naturally occurring radioactive sample from Alkharje City, J. Radioanal. Nucl. Chem. 269, 99-102.

Stoulos S., Manolopoulou M., Papastefanou C. (2003) Assessment of natural radiation exposure and radon exhalation from building materials in Greece, J. Environ. Radioact. 69, 225-240.

Turhan Seref (2009) Radiological impacts of the usability of Clay and Kaolin, as raw materials in manufacturing of structural building materials in Turkey, J. Radiol. Prot. 29, 75-83.

UNCEAR (1982) Ionization Radiation Sources and Biological Effects, Report of the General Assembly, with annexes, United Nations, New York.

UNSCEAR (2000) Sources and effects of ionizing radiation. Report of the United Nations Scientific Committee on the Effects of Atomic Radiation to the General Assembly, United Nations, New York, USA.

Wollenberg H.A., Smith R.A. (1990) A geochemical assessment of terrestrial gamma ray absorbed dose rates, Health Phys. 58, 183-189. 